\title{
UJI AKTIVITAS FRAKSI ETIL ASETAT BUAH GAMBAS (Luffa acutangula $($ L.) Roxb.) TERHADAP PENURUNAN KADAR GULA DARAH TIKUS PUTIH JANTAN (Rattus norvegicus)
}

\author{
Jyulianti Dinie Mhuspita Sari, Adam M. Ramadhan, Muhammad Amir Masruhim \\ Laboratorium Penelitian dan Pengembangan FARMAKA TROPIS, Fakultas Farmasi, \\ Universitas Mulawarman, Samarinda,Kalimantan Timur \\ Email:yuliantidms@yahoo.com
}

\begin{abstract}
Abstrak
Diabetes Melitus (DM) adalah penyakit kelainan metabolik yang dikarakteristikkan dengan hiperglikemia kronis serta kelainan metabolism karbohidrat, lemak dan protein yang diakibatkan oleh kelainan sekresi insulin. Pengobatan untuk penderitaa diabetes mellitus salah satunya dengan memanfaatkan tanaman sebagai pengobatan tradisional. Luffa acutangula (L.) Roxb. telah digunakan secara tradisional sebagai tanaman obat. Penelitian ini bertujuan untuk mengetahui rendemen, metabolit sekunder dan dosis efektif fraksi buah gambas dalam menurunkan kadar glukosa darah pada tikus putih jantan. Ekstraksi dilakukan secara maserasi dengan menggunakan pelarut etanol 80\%. Fraksinasi dilakukan dengan menggunakan metode fraksinasi cair-cair. Subjek penelitian berupa tikus putih jantan berjumlah 15 ekor tikus yang dibagi dalam 5 kelompok yaitu kelompok kontrol negatif menggunakan Na-CMC, kelompok kontrol positif menggunakan glibenklamid dengan dosis $0,09 \mathrm{mg} / 200 \mathrm{grBB}$ dan fraksi etil asetat buah gambas dengan varian dosis $(15 \mathrm{mg} / \mathrm{KgBB} ; 20 \mathrm{mg} / \mathrm{KgBB}$ dan $30 \mathrm{mg} / \mathrm{KgBB})$ yang diberikan secara oral dengan metode uji toleransi glukosa. Data diperoleh dari pemeriksaan kadar gula darah puasa, 30 menit setelah diinduksi glukosa dan pada menit ke-30, 45, 60, 90 dan 150 setelah diberi perlakuan. Rendemen fraksi etil asetat yang didapatkan sebanyak 0,793\%. Golongan metabolit sekunder yang terdeteksi didalam fraksi etil asetat buah gambas ialah alkaloid dan fenol. Pemberian fraksi etil asetat buah gambas dengan dosis $20 \mathrm{mg} / \mathrm{KgBB}$ memberikan hasil yang lebih baik terhadap penurunan kadar glukosa darah dibandingkan dengan dosis $15 \mathrm{mg} / \mathrm{KgBB}$ dan $30 \mathrm{mg} / \mathrm{KgBB}$.
\end{abstract}

Kata Kunci : Luffa acutangula (L.) Roxb, Uji Toleransi Glukosa darah, Tikus, Fraksi etil asetat

\begin{abstract}
Diabetes mellitus (DM) is a metabolic disorder characterized by chronic hyperglycemia and abnormal metabolism of carbohydrates, fats and proteins caused by abnormal insulin secretion. Treatment for diabetes mellitus afflictions one of them by using plants as traditional medicine. Luffa acutangula (L.) Roxb. has been traditionally used as a medicinal plant. This study aims to determine the yield, secondary metabolites and effective dose fractions of fruit squash in lowering blood glucose levels in male rats. Extraction is done by maceration using $80 \%$ ethanol. Fractionation performed using liquidliquid fractionation. The subject of research in the form of white male rats of 15 rats were divided into 5 groups: negative control group using $\mathrm{Na}-\mathrm{CMC}$, positive control group using glibenclamide at a dose of $0.09 \mathrm{mg} / 200 \mathrm{grBB}$ and ethyl acetate fraction fruit gambas with
\end{abstract}


variants dose (15 mg / KgBW; $20 \mathrm{mg} / \mathrm{kg}$ and $30 \mathrm{mg} / \mathrm{kg}$ ) were administered orally with a glucose tolerance test method. Data obtained from the examination of fasting blood sugar levels, 30 minutes after induction of glucose and at minute 30, 45, 60, 90, and 150 after being treated. The yield of ethyl acetate fraction obtained as much as $0.793 \%$. Class of secondary metabolites were detected in the ethyl acetate fraction is the luffa fruit alkaloids and phenols. Provision of ethyl acetate fraction fruit squash at a dose of $20 \mathrm{mg} / \mathrm{KgBW}$ give better results on reducing blood glucose levels compared with a dose of $15 \mathrm{mg} / \mathrm{kg}$ and 30mg / KgBW.

Key Words : Luffa acutangula (L.) Roxb, Glucose tolerance test, Rats, Ethyl cetate fraction

\title{
PENDAHULUAN
}

Rakyat Indonesia telah mengenal berbagai jenis tanaman obat dan memanfaatkannya untuk menjaga kesehatan dan pengobatan penyakit. Pengobatan tersebut diperoleh berdasarkan pengetahuan secara empiris dan dipraktekkan secara turun temurun sehingga upaya pemeliharaan kesehatan melalui pengobatan tradisional memegang peranan penting (Sahputra, 2008).Diabetes mellitus adalah suatu gangguan metabolisme glukosa yang ditandai dengan hiperglikemia kronik.Diabetes mellitus khususnya tipe II merupakan kasus terbesar di Indonesia lebih dari 90\% penderita (Gyuton \& Hall, 2006).Penderita diabetes mellitus tipe II secara esensi mempunyai 2 kelainan dasar, yaitu pertama resistensi terhadap ambilan glukosa yang dimedia insulin dan kedua disfungsi sel beta (Hendromartono, 2002).Salah satu tanaman yang dapat berkhasiat sebagai obat ialah tanaman gambas (Luffa actunagula (L.) Roxb). Tanaman gambas memiliki khasiat antara lain sebagai antioksidan, antidiabetes, hepatoprotektif, antipoliferatif, antikataleptik, antidiabetes, antimikroba, analgesik selain itu dapat sebagai antineoplastik dan juga masalah penyakit pada usus, pembesaran limfa, penyakit kuning dan pencahar. Khasiatkhasiat tersebut terutama terkandung pada bagian daun, buah, akar, buah biji, dan batang.

Tujuannya dilakukan penelitian ini untuk mengetahui rendemen, metabolit sekunder dan dosis efektif fraksi etil asetat buah gambas terhadap penurunan kadar glukosa darah pada tikus putih jantan.

\section{METODOLOGI PENELITIAN}

\section{Bahan}

Bahan yang digunakan pada penelitian ini adaalah simplisia buah gambas, aquadest, glukosa, pelarut etanol $80 \%, n$-heksana, etil asetat, Na-CMC 1\%, glibenklamid, $\mathrm{HCl} 2 \%, \mathrm{HCl}$ pekat, pereaksi Dragendroff, pereaksi Mayer, serbuk $\mathrm{Mg}, \mathrm{CH}_{3} \mathrm{COOH}$ anhidrat, $\mathrm{H}_{2} \mathrm{SO}_{4}$ dan $\mathrm{FeCl}_{3}$.

\begin{abstract}
Alat
Peralatan yang digunajkan dalam penelitian ini antara lain Peralatan yang digunakan dalam penelitian ini antara lain toples kaca, rotary evapator dan water bath, corong pisah, timbangan analitik, glukometer, glukotest strip test, penangas air, lumpang dan alu, oral sonde, alat timbang, gelas ukur, gelas kimia, pipet tetes, pipet volume dan propipet, sendok tanduk dan spatula statif dan klem,oven, erlenmeyer, tabung reaksi, rak tabung reaksi cawan, spoit dan inkubator.
\end{abstract}




\section{CARA KERJA}

\section{Prosedur Ekstraksi dan Fraksinasi}

Buah gambas yang dicuci bersih dirajang menjadi potongan yang lebih kecil, lalu dikeringkan menggunakan oven pada suhu $160^{\circ}$ C. simplisia kering sebanyak 310 gram lalu dimasukkan dalam toples maserasi, lalu direndam pelarut etanol $80 \%$ sebanyak $5 \mathrm{~L}$ selama 3 hari sambil sesekali dilakukan pengadukan, kemudian filtrate disaring. Residu direndam kembali dengan etanol $80 \%$ dan dibiarkan selama 3 hari kemudian disaring kembali, lalu filtrat yang terkumpul dipekatkan dengan rotary evaporatorsehingga diperoleh ekstrak kasar buah gambas sebanyak21,5 mg. Ekstrak kasar kemudian difraksinansi, sebanyak 21 gram ektrak kasar dilarutkan dengan $50 \mathrm{~mL}$ aquadest dan 50 mL n-heksan (1:1)kemudian di gojog di dalam corong pisah. Didiamkan hingga terbentuk 2 lapisan.Lapisan bawah dikeluarkan (larutan air) dan lapisan atas (fraksi $n$-heksana) dikeluarkan dan diuapkan pelarutnya.Kembudian lapisan bawah (larutan air) ditambahkan pelarut $n$-heksana kembali digojog hingga lapisan atas tetap bening. Setelah bening kemudian pelarut $n$-heksana digantikan dengan pelarut etil asetat dan prosedur fraksinansi diulang kembali hingga diperoleh fraksi etil asetat sebanyak gram 2,305 gr.

\section{Pengujian Metabolit Sekunder}

Fraksi etil asetat buah gambas dilakukan uji metabolit sekunder antara lain alkaloid, flavonoid, streroid/terpenoid, fenol dan saponin.Fraksietil asetatterlebih dahulu dilarutkan dengan etanol. Uji alkaloid dengan menambahkan $\mathrm{HCl} 2 \%$, kemudian pereaksi Dragendorff, positif ditandai dengan endapan jingga kecoklatan dan pereaksi Mayer, positif ditandai endapan putih kuning. Uji flavonoid dengan pemanasan dan penambahan serbuk $\mathrm{Mg}$ serta $\mathrm{HCl}$ pekat dikocok, positif ditandai larutan merah, kuning/jingga.Uji steroid/terpenoid menggunakan pereaksi $\mathrm{CH}_{3} \mathrm{COOH}$ anhidrat, $\mathrm{CHCl}_{3}$ dan $\mathrm{H}_{2} \mathrm{SO}_{4}$ pekat, positif ditandai dengan terbentuknya cincin merah kecoklatan/ungu.Uji fenol dengan penambahan pereaksi $\mathrm{FeCl}_{3}$, positif ditandai dengan perubahan warna biru sampai hitam.Sedangkan uji saponin yaitu dengan menambahkan aquades kemudian dikocok, positif ditandai terbentuk buih yang tidak hilang jika ditambahkan $\mathrm{HCl} 10 \%$.

\section{Pengujian Penurunan Kadar Glukosa Darah}

Hewan uji dibagi dalam 5 kelompok. Sebelum diberi perlakuan, semua tikus dipuasakan selama 24 jam (minum tetap diberikan). Semua tikus yang telah dipuasakan ditimbang berat badannya, kemudian diperiksa kadar puasa (t1), stelah itu semua tikus diinduksi glukosa sebesar $3 \mathrm{~g} / \mathrm{KgBB}$ per oral. Setelah 30 menit, semua tikus diperiksa kadar gula darah sesudah diinduksi glukosa (t2). Selanjutnya, semua tikus diberi sediaan peroral, untuk kelompok kontrol negatif (K-) diberikan CMC $1 \%$, untuk kelompok kontrol positif $(\mathrm{K}+)$ diberikan glibenklamid dengan dosis $0,09 \mathrm{~g} / \mathrm{KgBB}$, dan untuk kelompok perlakuan diberi Fraksi etil asetat buah gambas dengan masing-masing dosis (15 $\mathrm{mg} / \mathrm{KgBB} ; 20 \mathrm{mg} / \mathrm{KgBB}$ dan $30 \mathrm{mg} / \mathrm{KgBB}$ ), kemudian kadar gula darah tikus diperiksa pada menit ke 15, 30, 60 dan 120 setelah perlakuan (t3 sampai t6). Semua sampel darah diambil dari vena ekor tikus dan kadar gula dara diukur dengan glukometer.

\section{HASIL DAN PEMBAHASAN}

\section{Rendemen}

Berikut merupakan tabel data perhitungan rendemen dari ekstrak buah gambas: 
Tabel 1. Berat sampel dan ektrak buah gambas

\begin{tabular}{llc}
\hline No & Sampel dan Ekstrak & Berat $(\mathrm{g})$ \\
\hline 1 & Sampel segar & 1600 \\
2 & Sampel kering & 310 \\
3 & Ekstrak etanol & 21,5 \\
4 & Fraksi etil asetat & 2,305 \\
\hline
\end{tabular}

Tabel 2. Data Rendemen ekstrak buah gambas

\begin{tabular}{llccc}
\hline \multirow{2}{*}{ No } & \multirow{2}{*}{ Ekstrak } & \multicolumn{3}{c}{ Rendemen ekstrak (\%) terhadap } \\
\cline { 3 - 5 } & Sampel segar & $\begin{array}{c}\text { Sampel } \\
\text { kering }\end{array}$ & $\begin{array}{c}\text { Ekstrak } \\
\text { etanol }\end{array}$ \\
\hline 1 & Ekstrak etanol 80\% & 1,343 & 6,935 & \\
2 & Fraksi etil asetat & 0,144 & 0,793 & 10,720 \\
\hline
\end{tabular}

Dari tabel 2 diketahui bahwa rendemen ekstrak kasar terhadap sampel segar dan kering berturut-turut adalah 1,343\%,0,144\%, 6,935\%,0,793\% dan 10,720\% . Rendemen tertinggi dari ekstrak buah gambas adalah fraksi etil asetat, hasil tersebut menunjukkan bahwa fraksi etil asetat terhadap ekstrak etanol memiliki kandungan senyawa nonpolar yang lebih banyak daripada senyawa polarnya.

\section{Metabolit Sekunder}

Identifikasi metabolit sekunder pada penelitian ini dilakukan terhadap fraksi etil asetat yang diduga memiliki aktivitas antidiabetes. Hasil identifikasi metabolit sekunder fraksi etil asetat daun libo dapat dilihat pada Tabel 3.

Tabel 3.Hasil identifikasi golongan metabolit sekunder fraksi etil asetat buah gambas

\begin{tabular}{lccccc}
\hline \multirow{2}{*}{ Fraksi } & \multicolumn{5}{c}{ Metabolit Sekunder } \\
\cline { 2 - 5 } & Alkaloid & Flavonoid & $\begin{array}{c}\text { Steroid/ } \\
\text { terpenoid }\end{array}$ & Fenol & Saponin \\
\hline $\begin{array}{l}\text { Fraksi Etil Asetat } \\
\text { Daun Gambas }\end{array}$ & + & - & - & + & - \\
\hline
\end{tabular}

Keterangan:

(+): Teridentifikasi golongan metabolit sekunder

(-) : Tidak teridentifikasi golongan metabolit sekunder

Berdasarkan hasil metabolit sekunder pada tabel 3 menunjukkan bahwa fraksi etil asetat buah gambas terdeteksi golongan metabolit sekunder alkaloid dan fenol.

\section{Penentuan Dosis Efektif}

Pengukuran kadar gula darah dilakukan sebanyak enam kali yaitu kadar gula darah sebelum dan sesudah diinduksi glukosa ( $\mathrm{t} 1$ dan $\mathrm{t} 2$ ), serta kadar gula darah pada menit ke 30, 45, 60, 90, dan 150 setelah perlakuan (t3 sampai t6). Hasil pengukuran dapat dilihat pada tabel 4. 
Tabel 4. Pengukuran KGD rata-rata setelah perlakuan

\begin{tabular}{lcccccc}
\hline \multicolumn{1}{c}{ Kelompok } & $\mathbf{t 1}$ & $\mathbf{t 2}$ & $\mathbf{t 3}$ & $\mathbf{t 4}$ & $\mathbf{t 5}$ & $\mathbf{t 6}$ \\
\hline K(+) glibenklamid & 113 & 143 & 106 & 105 & 88 & 78 \\
K(-) CMC & 119 & 152 & 119 & 107 & 114 & 117 \\
D1 (15mg) & 110 & 130 & 117 & 128 & 110 & 104 \\
D2 (20mg) & 113 & 125 & 110 & 104 & 103 & 96 \\
D3 (30mg) & 102 & 137 & 134 & 141 & 124 & 108 \\
\hline
\end{tabular}

Keterangan :

t1 : Pemeriksaan Kadar Gula Darah Puasa

t2 : Pemeriksaan Kadar Gula Darah Setelah 30 menit diinduksi Glukosa

t3 : Pemeriksaan Kadar Gula Darah Setelah Pemberian Sediaan pada tikus ke-15

t4 : Pemeriksaan Kadar Gula Darah Setelah Pemberian Sediaan pada tikus ke-30

t5 : Pemeriksaan Kadar Gula Darah Setelah Pemberian Sediaan pada tikus ke-60

t6 : Pemeriksaan Kadar Gula Darah Setelah Pemberian Sediaan pada tikus ke-120

Berdasarkan hasil penelitian diatas, Pada t2 (kadar gula darah 30 menit setelah diinduksi glukosa) untuk semua perlakuan, terlihat kenaikan gula darah yang cukup tinggi. Menunjukkan telah terjadi penyerapan glukosa oleh tubuh tikus dikarenakan pengaruh fisiologis dari tubuh tikus sendiri.untuk membandingkan kenaikan dan penurunan rata-rata kadar gula darah tikus sebelum dan sesudah diinduksi glukosa dan setelah perlakuan antara kelompok kontrol negatif (CMC 1\%), Fraksi etil asetat buah gambas, dan kontrol positif (Glibenklamid), dapat dilihat pada grafik dibawah ini.

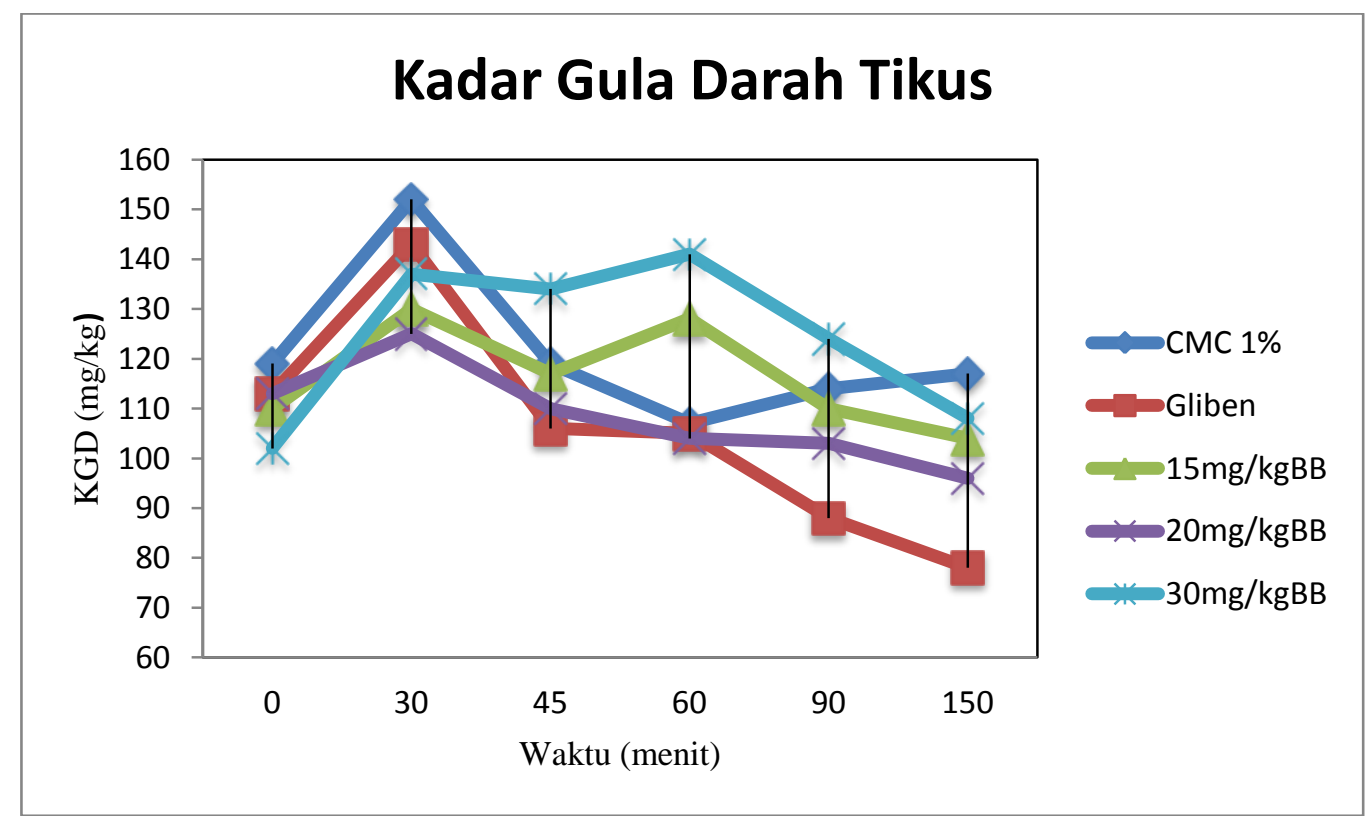

Berdasarkan grafik rata-rata kadar gula darah tikus, dapat dilihat perbedaan penurunan kadar gula darah terjadi pada tikus setelah 15 menit pemberiaan sediaan uji (t3). Kontrol positif mengalami penurunan yang sangat signifikan dimulai dari t3 sampai 
dengan t6, kontrol negatf mengalami penurunan dari t3 sampai t4 tetapi pada saat $\mathrm{t} 5$ sampai t6 kontrol negatif mengalami kenaikan gula darah, selanjutnya pada sediaan uji dosis 15 dan $30 \mathrm{mg} / \mathrm{kg}$ BB mengalami kenaikan glukosa darah pada $\mathrm{t} 4$ dan kemudian mengalami penurunan glukosa darah pada t5 sampai t6, sedangkan sediaan uji dosis 20 $\mathrm{mg} / \mathrm{kg}$ BB mengalami penurunan yang signifikan dimulai dari t3 sampai t6. Maka dapat disimpulkan bahwa pada sediaan uji dengan dosis $20 \mathrm{mg} / \mathrm{kg}$ BB memberikan hasil yang lebih baik dalam menurunkan kadar glukosa darah pada tikus dibandingkan dengan dosis sediaan 15 dan $30 \mathrm{mg} / \mathrm{kg}$ BB.

Digunakan glibenklamid sebagai obat pembanding karena dapat meningkatkan sekresi insulin. Glibenklamid hanya efektif pada diabetes mellitus tipe 2 yang keadaan diabetesnya tidak begitu berat dan yang sel betanya masih bekerja cukup baik (Tjay dan Rahardja, 2007), dilihat dari grafiknya pun glibenklamid memberikan efek yang cukup baik untuk menurunkan kadar glukosa darah. Pada sediaan uji 15, 20 dan $30 \mathrm{mg} / \mathrm{kg} \mathrm{BB}$, dosis $20 \mathrm{mg} / \mathrm{kg}$ BB menunjukan hasil penurunan kadar glukosa darah yang signifikan dibandingkan dengan dosis 15 dan $30 \mathrm{mg} / \mathrm{kg}$ BB. Pada dosis 15 dan $30 \mathrm{mg} / \mathrm{kg} \mathrm{BB}$ seharusnya pada waktu t4 kadar glukosa darah mengalami penurunan, diduga pada tikus untuk sediaan uji dosis 15 dan $30 \mathrm{mg} / \mathrm{kg}$ BB mengalami stress dan cemas yang termasuk dalam faktor yang mempengaruhi kadar glukosa darah, dimana pada saat tikus mengalami stress dan cemas maka memicu pengeluaran hormon adrenalin dan kortisol yang juga menyebabkan pelepasan glukosa hati sebagai respon "fight-or-flight" untuk meningkatkan ketersediaan glukosa, asam amino, dan asam lemak (Sherwood, 2001). Faktor-faktor yang mempengaruhi kadar glukosa darah ialah Faktor-faktor yang dapat menimbulkan stres seperti fisik (trauma, pembedahan, panas, atau dingin hebat); fisiologis (olahraga berat, syok perdarahan, nyeri); psikologis atau emosi (rasa cemas, ketakutan, kesedihan); dan sosial (konflik pribadi, perubahan gaya hidup) (Sherwood, 2001).

Data yang didapat kemudian diuji sebaran datanya menggunakan ANOVA satu arah dan membandingkan antara dosis ekstrak dengan kontrol negatif diperoleh $\mathrm{F}$ hitung < $\mathrm{F}$ tabel, dimana $\mathrm{F}$ hitung 1,653 lebih kecil dari $\mathrm{F}$ tabel 3,10. Hal ini berarti bahwa pada fraksi etil asetat buah gambas dalam menurunkan kadar glukosa darah tikus tidak memiliki efek yang signifikan. Dalam kata lain fraksi etil asetat buah gambas dalam menurunkan kadar glukosa darah varians dosis ekstrak tidak memiliki efek menurunkan glukosa darah yang baik. Namun realistisnya pada pengujian ini fraksi buah gambas memberikan efek penurunan glukosa darah jika dibandingkan dengan kontrol negatif.

Dosis yang memberikan efek yang baik dalam menurunkan glukosa darah ialah dosis $20 \mathrm{mg} / \mathrm{kg}$ BB. Dimana pada fraksi etil asetat buah gamabs terdapat senyawa metabolit sekunder alkaloid dan fenol yang diduga efeknya dapat menurunkan kadar glukosa darah. Mekanisme dari senyawa metabolit alkaloid dan fenol mempunyai kemiripan dengan glibenklamid ,karena kedua senyawa metabolit mengandung elektron yang bisa didonorkan pada radikal bebas. Glibenklamid menyebabkan hipoglikemia dengan cara menstimulasi pelepasan insulin dari sel $\beta$ pankreas, meningkatkan pelepasan insulin dari pankreas dan meningkatkan sensitivitas sel-sel asaran perifer terhadap kadar insulin (Gliman,2007). Senyawa alkaloid memiliki kemampuan untuk menghentikan reaksi rantai bebas secara efisien. Senyawa radikal turunan dari senyawa amina ini memiliki tahap terminasi yang sangat lama. Menurut Abdelmoaty (2010) Alkaloid juga dapat menghambat absorpsi glukosa diusus Senyawa fenol memiliki kemampuan dalam meningkatkan sekresi insulin, mencegah kerusakan pada sel $\beta$ pankreas dan meningkatkan fungsi dari sel $\beta$ pankreas sehingga dapat menimbulkan efek hipoglikemia pada tikus.

Maka dari hasil penelitian yang dilakukan dapat disimpulkan bahwa, jika data hasil glukosa darah dihitung secara sistematik menggunakan Anava satu arah maka data yang dihasilkan tidak signifikan dan fraksi etil asetat tidak beraktivitas baik dalam menurunkan 
kadar glukosa darah. Tetapi jika dilihat dari kandungan senyawa metabolit yang terkandung didalam fraksi etil asetat buah gambas, maka data yang dihasilkan pada dosis $15 \mathrm{mg} / \mathrm{kg} \mathrm{BB}, 20 \mathrm{mg} / \mathrm{kg}$ BB dan $30 \mathrm{mg} / \mathrm{kg}$ BB fraksi etil asetat buah gambas beraktivitas menurunkan kadar glukosa darah. Sehingga didapatkan dosis yang paling efektif menurunkan kadar glukosa darah ialah dosis $20 \mathrm{mg} / \mathrm{kg}$ BB.

\section{KESIMPULAN}

1. Rendemen ekstrak kasar terhadap sampel segar dan kering berturut-turut adalah $1,343 \%, 0,144 \%, 6,935 \%, 0,793 \%$ dan $10,720 \%$. Rendemen tertinggi dari ekstrak buah gambas adalah fraksi etil asetat, hasil tersebut menunjukkan bahwa fraksi etil asetat terhadap ekstrak etanol memiliki kandungan senyawa nonpolar yang lebih banyak daripada senyawa polarnya

2. Hasil pengujian golongan metabolit sekunder fraksi etil asetat buah gambas (Luffa acutangula (L.) Roxb,) adalah alkaloid dan fenol.

3. Dosis efektif fraksi etil asetat buah gambas dalam menurunkan kadar glukosa darah tikus putih jantan ialah $20 \mathrm{mg} / \mathrm{kg}$ BB.

\section{DAFTAR PUSTAKA}

Tjay, T.H., dan Rahardja, K. 2007. Obat-Obat Penting, Khasiat, Penggunaaan dan EfekEfek Samping (Edisi VI). Elex Media Komputindo : Jakarta.

Gyuton AC and Hall JE. 2006. Textbook Of Medical Physiology. Philadelphia : W.B Sounders Company.

Hendromartono. 2002. Obesitas Sebagai Faktor Risiko Penyakit Kardiovaskuler. Majalah Kedokteran Indonesia.

Gliman, A.G. 2007. Dasar Farmakologi Terapi.Volume 2. Penerjemah: Cucu Aisyah. EGC : Jakarta.

Abdelmoaty, M.A., Ibrahim, M.A., Ahmed, N.S., Abdelaziz, M.A. 2010. Confirmatory Studies in the Antioxidant and Antidiabetic Effect of Quercetin in Rats. India : Clinical Biochemistry 25(2):188-192. 